\title{
FLESHING OUT THE PROVISIONS FOR PROTECTING FOREIGN INVESTMENT
}

\author{
Mohammad Belayet Hossain ${ }^{1}$ \\ School of Law, Chittagong Independent University of Bangladesh (CIUB) \\ Email: hasan1215@yahoo.com; galib@ciu.edu.bd
}

\begin{abstract}
This article aims to analyse the jurisprudence developed by international courts and tribunals with regard to the standard of treatment of foreign investors, with particular focus on issues concerning expropriation. In doing so, it will analyse some of the standard-setting decisions and far-reaching implications of: the IranUS Claims Tribunals, the International Court of Justice and the ICSID. It will also examine the recent trend in jurisprudence on the so-called regulatory takings of foreign investment. It will explore: (a) how the decisions of international courts and tribunals have 'fleshed out' the principles of the law of foreign investment on, inter alia, the definition of expropriation and nationalisation and determination of the quantum of compensation; (b) how the frontiers of expropriation have been extended to cover regulatory takings.
\end{abstract}

Key words: Foreign investment, expropriation, quantum of compensation, the ICSID, International Court of Justice.

\section{A. INTRODUCTION}

In the absence of a global treaty on the law of foreign investment, international courts, claims commissions and tribunals have tried to flesh out the main principles of the part of the role of foreign investment and especially those relating to the requirements for a lawful expropriation and the nature of compensation, damages, reparation or restitution for:

1. lawful expropriation;

2. the illegal or confiscatory actions of states.

Where the main principles pertaining to the area are not fully settled and the state practice and the efforts made within and outside of the UN point in conflicting directions, the decisions of international courts and tribunals on these matters have been relied upon to deduce the rules applicable not only to expropriation and

1 Mohammad Belayet Hossain, Lecturer, School of Law, Chittagong Independent University of Bangladesh (CIUB). Obtained Diploma in Law from University of London, UK; LLB (Hons.) from University of Northumbria, UK, LLM in Commercial and Corporate Law from University of London, UK, PhD candidate in Universiti Utara Malaysia. 
compensation, but also to the meaning of the terms 'fair and equitable treatment', the 'due process of law', and 'full protection and security'.

\section{B. THE HISTORY OF PROTECTING FOREIGN INVESTMENT}

Indeed, the decisions of international courts, claims commissions and arbitration tribunals have played a major role in articulating the international standards of treatment applicable to foreign investors. Traditionally, the treatment of aliens under international law of state responsibility has been relied upon by international courts, claims commissions and tribunals to provide legal remedy to foreign investors when their investment was expropriated or unlawfully impaired by a foreign government. As stated by Asante (Asante, note 17: 590).

'Traditional principles of customary international law relating to investments revolve around the law of state responsibility for injury to aliens and alien property. According to this doctrine, which was developed in the nineteenth century, host states are enjoined by international law to observe an international minimum standard in the treatment of aliens and alien property.'

\section{THE CALVO DOCTRINE}

However, it was not until the inter-war period that the idea of submitting investment disputes to a third party was accepted by those states, which subscribed to the Calvo doctrine. The requirement to accord international minimum standard did not include the right of states, let alone of private investors, to have investment disputes with host states entertained by an international tribunal or commercial arbitration.

One of the core elements of the Calvo doctrine was that the home states had to abstain from interference in disputes over the treatment of foreigners and their property rights. This meant, inter alia, abstaining from the use of 'gunboat diplomacy' or diplomatic protection by investor countries in favour of their nationals doing business abroad.

Even the provisions of the modern FCN treaties concluded in the aftermath of WW II were limited to providing for adjudication before the ICJ of certain disputes between the treaty parties (i.e. state-to-state disputes). The norm of the day was to protect national investors doing business abroad through diplomatic protection by invoking the 'international minimum standard'.

A. Relevant case-law

Supporting the idea behind diplomatic protection, the PCIJ held in the Mavrommatis Palestine Concessions case (jurisdiction) (Greece v UK) that:

\begin{tabular}{ll|l}
\hline Yustisia Vol. 7 Number 3 (Sept.-Dec. 2018) & Fleshing Out The Provisions ... & 407
\end{tabular} 
'It is an elementary principle of international law that a state is entitled to protect its subjects, when injured by acts contrary to international law committed by another state, from whom they have been unable to obtain satisfaction through the ordinary channels.' (PCIJ Rep., Series A, No.2: 12)

Cases like Neer claim (USv Mexico) supported the notion that international law required states to treat aliens according to an international minimum standard. Indeed, the Neer claim decided by the Mexico-United States General Claims Commission in 1926 has been relied upon to support the doctrine of an international minimum standard of treatment of foreign investors in international law:

'the propriety of governmental acts should be put to the test of international standards ... the treatment of an alien, in order to constitute an international delinquency, should amount to an outrage, to bad faith, to wilful neglect of duty, or to an insufficiency of governmental action so far short of international standards that every reasonable and impartial man would readily recognize its insufficiency.' (Brownlie, I, 2003: 503)

Similar views were expressed by the ICJ in the Barcelona traction case (Barcelona traction, light and power co case (Belgium v Spain), ICJ reports $1970: 3$ ).

The classic and often cited case pronouncing the standard of treatment to be accorded to foreign investors is the Chorzow factory case (indemnity) (merits) in which the Permanent Court of International Justice (PCIJ) relied on the doctrine of state responsibility to provide legal remedy to Germany (Chorzow factory case, 1928: 29). After finding that Poland had violated the Geneva Convention of 1922 between Germany and Poland on Upper Silesia, the Court held that it is a principle of international law, and even a general conception of law, that any breach of an engagement involves an obligation to make reparation.' The Court held that:

'The action of Poland which the Court has judged to be contrary to the Geneva Convention is not an expropriation - to render which lawful only the payment of fair compensation would have been wanting; it is a seizure of property, rights and interests which could not be expropriated even against compensation, save under the exceptional conditions fixed by Article 7 of the said Convention.

It follows that the compensation due to the German Government is not necessarily limited to the value of the undertaking at the moment of dispossession, plus interest to the day of payment. This limitation would only be admissible if the Polish Government had had the right to expropriate, and if its wrongful act consisted merely in not having paid to the two Companies the just price of what was expropriated.

The essential principle contained in the actual notion of an illegal act - a principle which seems to be established by international practice and in particular by

\begin{tabular}{l|ll}
\hline 408 & Yustisia Vol. 7 Number 3 (Sept.-Dec. 2018) & Fleshing Out The Provisions ...
\end{tabular} 
decisions of arbitral tribunals - is that reparation must, as far as possible, wipe out all the consequences of the illegal act and re-establish the situation which would, in all probability, have existed if that act had not been committed

(Chorzow factory case, 1928: 46-48)

The opinion of the court in this case has been relied upon heavily by international courts and tribunals established in later years, among which the IranUS Claims Tribunal is a prominent example.

\section{DEFINITION OF EXPROPRIATION AND NATIONALISATION} (Schachter, O, 1984 : 130)

As noted by Asante, 'the standards prescribed by traditional international law with respect to alien property are predicated on the basic assumptions prevalent in a liberal regime of private property, in particular the inviolability of private property and sanctity of contract (Asante, note $17: 595$ ). Therefore, a compulsory taking of foreign property amounts to expropriation or nationalisation giving rise to compensation.

There is a great deal of literature on defining what constitutes a 'taking of property', commonly known as expropriation or nationalisation. The meaning of these terms has also been the preoccupation of international courts and tribunals on a number of cases referred to them. Some of the more recent cases seek to cover not only direct, express or outright cases of compulsory taking of foreign property, but also indirect 'constructive taking' or 'creeping expropriation' such as that considered by the ICJ in the ELSI case (Case concerning Elettronica Sicula S.p.A, 1989: 119).

\section{E. Draft Convention on state Responsibility 1961}

The 1961 Draft Convention on state Responsibility set the modern tone to the definition of expropriation or taking of foreign private property in the following words:

'(a) A 'taking of property' includes not only an outright taking of property but also any such unreasonable interference, use, enjoyment, or disposal of property as to justify an inference that the owner thereof will not be able to use, enjoy, or dispose of the property within a reasonable period of time after the inception of such interference.

(b) A 'taking of the use of property' includes not only an outright taking of property but also any unreasonable interference with the use or enjoyment of property for a limited period of time.' (Draft Convention on the International Responsibility of states for Injury to Aliens, AJIL,1961: 545)

Yustisia Vol. 7 Number 3 (Sept.-Dec. 2018) Fleshing Out The Provisions ... 


\section{A. Relevant case-law}

Many of the decisions of international tribunals, especially those of the IranUS Claims Tribunal, have followed this definition of taking of property. For instance, in the Starrett Housing Corporation v Iran (interlocutory order) the Tribunal held that since the Starrett company, an American company, had been deprived of the effective use, control and benefits of their property rights by the Government of Iran in the aftermath of the Islamic Revolution it amounted to 'creeping' or 'constructive' expropriation:

'(I)t is recognised in international law that measures taken by a state can interfere with property rights to such an extent that these rights are rendered so useless that they must be deemed to have been expropriated, even though the state does not purport to have expropriated them and the legal title to the property formally remains with the original owner.'( 23 ILM 1090: 1984); Iran-US C.T.R.122 : 1983)

In the Tippetts $v$ TAMS-AFFA case the Tribunal suggested that 'constructive expropriation' occurs when 'events demonstrate that the owner was deprived of fundamental rights of ownership and it appears that this deprivation is not merely ephemeral.'( 6 Iran-US C.T.R.219:1984)

When employing the term 'deprivation' to describe the acts and omissions of the Iranian government, the Tribunal held in this case that '(a) deprivation or taking of property may occur under international law through interference by a state in the use of that property or with the enjoyment of its benefits, even where legal title to the property is not affected.'

In the Amoco International Finance Corporation $v$ Iran case the issue involved was the nationalisation of the Iranian oil industry under the Single Article Act in the aftermath of the Islamic Revolution during which Khmeco, an Iranian company jointly owned and managed by Amoco, was also nationalised. In delivering its award the Tribunal held that:

'Expropriation, which can be defined as a compulsory transfer of property rights, may extend to any right which can be the object of a commercial transaction i.e. freely sold and bought, and thus has a monetary value. It is because Amoco's interests under the Khemco Agreement have such an economic value that the nullification of those interests by the Single Article

Act can be considered as a nationalisation.' (15 Iran-US C.T.R. 189)

The Tribunal also touched on the capacity of a state to nationalise or expropriate for a public purpose:

'A precise definition of the 'public purpose' for which an expropriation may

be lawfully decided has neither been agreed upon in international law

\begin{tabular}{l|ll}
\hline 410 & Yustisia Vol. 7 Number 3 (Sept.-Dec. 2018) & Fleshing Out The Provisions ...
\end{tabular} 
nor even suggested. It is clear that, as a result of the modern acceptance of the right to nationalise, this term is broadly interpreted, and that states, in practice, are granted extensive discretion.'

Accordingly, the Tribunal held that Amoco's rights and interests under the Khemco Agreement, including its shares in Khemco, were lawfully expropriated by Iran and then went on to examine the rules to be applied in determining the level of compensation to be paid in such a circumstance.

Relying on the Chrozow case, the Tribunal in the Amoco case was drawing a distinction between the unlawful confiscation of foreign property, and lawful expropriation or nationalisation. In other words, to be lawful, an expropriation should be non-discriminatory and must be for a public purpose (Limaco case, 1981: 58-59).

Thus, lawful taking of foreign property is expropriation which would attract compensation, but illegal expropriation or confiscation such as that which occurred in relation to Chorzow Factory would give rise to state responsibility and attract reparation or restitution. According to Bowett, the principles underlying the Chorzow judgement and Amoco award are as follows:

'(i) A clear distinction must be made between lawful and unlawful expropriations.

(ii) For unlawful expropriations, international law requires restitutio in integrum, or, if impossible, its financial equivalent.

(iii) For a lawful expropriation the obligation is to pay 'fair compensation', or 'the just price of what was expropriated' (Bowett, 1988: 49-74).

Accordingly, the Tribunal concluded that Amoco was deprived by the Iranian Government of its contractual rights under the Khemco Agreement, and the compensation due was related to these rights. Khemco was considered to be a going concern at the time of expropriation and going concern value was the measure of compensation in this case:

'Going concern value encompasses not only the physical and financial assets of the undertaking, but also the intangible valuables which contribute to its earning power, such as contractual rights (supply and delivery contracts, patent licences and so on), as well as goodwill and commercial prospects.' (Amoco International Finance Corporation v Iran, 1987: para. 264)

The Amoco case followed the principles declared in the Chorzow Factory case in recognising that illegal expropriation or confiscation would attract the rules of state responsibility. As stated by Bowett:

\begin{tabular}{|ll|l}
\hline Yustisia Vol. 7 Number 3 (Sept.-Dec. 2018) & Fleshing Out The Provisions ... & 411
\end{tabular} 
'( $t$ )he dictum of the Permanent Court in the Chorzow Factory case suggested that, as a consequence of the illegality of the act, restitution would be the primary remedy, and compensation would serve as a secondary remedy if restitution were not possible.'(Bowett, 1988: 59-60)

In the Texaco $v$ Libya case (52 ILR $389:$ 1977) the sole arbitrator found the nationalisation by Libya of the properties, rights, assets and interests of the two American oil companies to be in violation of the contracts made by these companies with the Libyan Government. The Tribunal held that:

'the recognition by international law of the right to nationalize is not sufficient ground to empower a state to disregard its commitments, because the same law also recognises the power of a state to commit itself internationally, especially by accepting the inclusion of stabilisation clauses in a contract entered into with a foreign private party ... Thus, in respect of international law of contracts, a nationalisation cannot prevail over an internationalised contract, containing stabilisation clauses, entered into between a state and a foreign private company'

In the Aminoil case (21 ILM 976)) the issue was the legality of a Kuwait Decree Law terminating the concession agreement with Aminoil, an American oil company, against compensation to be assessed by a Kuwaiti 'Compensation Committee'. The Tribunal held that Kuwait had satisfied the international law requirements for such termination of concession agreement: 'the "take-over" of Aminoil's enterprise was not, in 1977, inconsistent with the contract of concession, provided always that the nationalisation did not possess any confiscatory character'.

\section{F. DETERMINATION OF THE QUANTUM OF COMPENSATION (Schachter, O, 1984: 121-130 and Mendelson, W.H, 1985: 414)}

Although, as seen above, the recent BITs and RTAs incorporate the Hull Formula for compensation, there is no universal support in jurisprudence for this position, especially in the cases decided by tribunals other than the Iran-US Claims Tribunal (4 Iran-US C.T.R.)

Rather, there seems to be more support for 'appropriate' or 'just' compensation.

\section{G. ESTABLISHING APPROPRIATE COMPENSATION}

In Texaco v Libya,(52 ILR 389, 1977 : para.87), Topco/Calasiatic (17 ILM 1978: p.3) and the Aminoil (Kuwait v American Independent Oil Co. case: 21 ILM 976, paras 143, 144) cases the Tribunals supported the view of appropriate compensation. However, whether it be 'just', 'appropriate' or 'prompt, adequate and effective'

412 Yustisia Vol. 7 Number 3 (Sept.-Dec. 2018) $\quad$ Fleshing Out The Provisions ... 
compensation, these vague concepts mean little in practical terms unless they are defined in concrete terms to demonstrate the differences between them. A generally accepted rule seems to be to award an amount based on the fair market value of the assets expropriated.

\section{A. Relevant case-law}

In the INA Corporation case, the Iran-US Claims Tribunal defined fair market value as:

'the amount which a willing buyer would have paid to a willing seller for the shares of a going concern, disregarding any diminution of value due to the nationalization itself or the anticipation thereof, and excluding consideration of events thereafter that might have increased or decreased the value of the shares.'( 8 Iran-US C.T.R. p.380)

A survey of the awards made by various tribunals demonstrates that the factors to be taken into account in awarding compensation are:

a. assets, whether tangible or physical assets, or 'book' assets such as debts or monies due;

b. interest on the value of the assets;

c. loss of future profits.

The practice seems to include of the first two factors in both lawful and unlawful 'taking' of foreign property, but the third one seems to be included in determining compensation only in cases of the unlawful taking of foreign property. When determining the interest on the value of the assets it seems to be an accepted practice to include interest over the period between the date of the taking of the property and the date of the award or its payment.

In stating what elements would have to be taken into account in determining the amount of compensation, the Tribunal in the Aminoil case held that 'the determination of the amount of an award of 'appropriate' compensation is better carried out by means of an enquiry into all circumstances relevant to the particular concrete case, than through abstract theoretical discussion.' Accordingly, the conclusion that the Tribunal reached is illustrative and of interest:

'[The Tribunal] considers it to be just and reasonable to take some measure of account of all the elements of an undertaking. This leads to a separate appraisal of the value, on the one hand of the undertaking itself, as a source of profit, and on the other of the totality of the assets, and adding together the results obtained.'

The elements taken into account by the Tribunal in determining the amount of compensation and the manner in which the Tribunal arrived at a figure of compensation are as follows:

\begin{tabular}{|ll|l}
\hline Yustisia Vol. 7 Number 3 (Sept.-Dec. 2018) & Fleshing Out The Provisions ... & 413
\end{tabular} 
Amounts due to Aminoil:

'(1) These are made up of the values of the various components of the undertaking separately considered, and of the undertaking itself considered as an organic totality - or going concern - therefore as a unified whole, the value of which is greater than that of its component parts, and which must also take account of the legitimate expectations of the owners. These principles remain good even if the undertaking was due to revert, free of cost, to the concessionary Authority in another 30 years, the profits having been restricted to a reasonable level.

(2) As regard the evaluation of the different concrete components that constitute the undertaking, the Joint Report furnishes acceptable indications concerning the assets other than fixed assets. But as regards the fixed assets, the 'net book value' used as a basis merely gives a formal accounting figure which, in the present case, cannot be considered adequate.

(3) For the purposes of the present case, and for the fixed assets, it is a depreciated replacement value that seems appropriate. In consequence, taking that basis for the fixed assets, taking the order of value indicated in the Joint Report for the non-fixed assets, and taking into account the legitimate expectations of the concessionaire, the Tribunal comes to the conclusion [of a specified figure due to Aminoil in compensation]'.

Another case where nationalisation was held lawful is Liamco (Libyan American Oil Co. (Liamco) v Libya, 62 ILR 139 : 1977)).

In this case the arbitrator rejected the argument that international law allowed the recovery of future profits in a lawful case of nationalisation. After analysing a number of cases of the Iran-US Claims Tribunal, Bowett rightly concludes that for unlawful taking three propositions are possible:

'(i) Loss of profits is relevant only up to the date of the award (Chorzow, Amoco International Finance).

(ii) 'Full value' may be awarded for an ad hoc or discrete taking - but this concept, to be consistent with (i), excludes loss of future profits beyond the date of the award so that 'going concern value' based on profits after that date conflicts with Chorzow.

(iii) A lower value - less than "full" - may be awarded in the case of a formal, systematic, large-scale nationalisation (Bowett, 1988: 69).

Indeed, invoking the pronouncements made by the PCIJ in the Chorzow Factory case, the Amoco Tribunal stated that the components enumerated by the Court as included in the value of the undertaking were of paramount interest:

414 Yustisia Vol. 7 Number 3 (Sept.-Dec. 2018) $\quad$ Fleshing Out The Provisions ... 
'They appertain to three categories: corporeal properties (lands, buildings, equipment, stocks), contractual rights (supply and delivery contracts) and other intangible valuables (processes, goodwill and "future prospects"). Using today's vocabulary, this would mean "going concern value", which is not a new concept after all.'

Amerasinghe sums up the conclusions of both the Chorzow and Amoco findings in the following words:

'What is important is that for a lawful taking only damnum emergens is payable as compensation, i.e., the value of the property, however, established lucrum cessans (lost future profits) and other consequential damage not being taken into account. For an unlawful taking it is damages and not merely compensation that are payable - this includes damnum emergens (value of the property), lucrum cessans (lost profits), and any other consequential damage that may be found and is directly connected with the taking of the property.' (Amerasinghe, C.F, 1994: 55-65)

After surveying the various awards made by the Iran-US Claims Tribunal, Bowett comes to the following conclusion:

'The position towards which the US-Iran Claims Tribunal now seems to be moving (and which Aminoil supports) is that there are, in fact, three "standards" of compensation i.e.

a. for an unlawful taking;

b. for a lawful ad hoc taking; and

c. for a lawful, general act of nationalisation.

And the clear implication is that the third standard is the lowest, which would accord with state practice and the trend in the General Assembly resolutions to move towards a concept of "appropriate" or "just" compensation.

Curiously, what is lacking in the jurisprudence is a clear explanation of the reasons for a difference in standards between (ii) and (iii), between the lawful ad hoc taking and the lawful general nationalisation.' (Bowett, 1988: 73)

\section{B. Recent clarifications}

Unfortunately, since Bowett's observation in 1988, no arbitral award made by the Iran-US Claims Tribunal seem to offer a satisfactory explanation of the reasons for a difference in standards between the two (Amerasinghe, 1994: 55-65)

What is more, the jurisprudence of the Iran-US Claims Tribunal should be treated with some caution since most of the early cases decided by the Tribunal tended to apply the provisions of the Treaty of Amity (a lex specialis) between the US and Iran, which had incorporated the Hull Formula, rather than the rules of customary

\begin{tabular}{ll|l}
\hline Yustisia Vol. 7 Number 3 (Sept.-Dec. 2018) & Fleshing Out The Provisions ... & 415
\end{tabular} 
international law (a lex generalis). Iran unsuccessfully argued in several cases before the Tribunal that the law to be applied by the Tribunal consisted of emerging rules of customary international law as developed by the UN instruments, including the CERD, supporting 'appropriate' compensation rather than the Hull formula, but the Tribunal was reluctant to accept this line of argument and appeared intent on relying either on the traditional rules of customary international law based on the pronouncements made in the Chorzow case or on the provisions of the Treaty of Amity supporting the Hull formula.

The ICSID tribunals have in recent years made their own contribution to clarifying the standard of treatment and nature of compensation available to foreign investors. For instance, in the S.D. Myers Inc. v Canada (www.dfait-maeci.ge.ca/ tnanac/gov-en.asp; NAFTA chapter 11 arbitration tribunal, 2000-2002), an ICSID tribunal sitting under the NAFTA drew, citing the Chorzow pronouncements, a clear distinction between the standard of compensation for otherwise lawful expropriation and the measure of damages for unlawful expropriation resulting from discrimination or violation of treaty obligations. The tribunal held that the quantum of expropriation in cases of otherwise lawful expropriations may not include the future earnings.

However, future earnings would be taken into account in cases of unlawful expropriations or denial of national treatment. In this case the tribunal held that denial of national treatment to foreign investors would be treated as a breach of NAFTA Article 1105(1) provisions and would thus give rise to compensation.

This is an interesting development within international law, which is liable to make national treatment the focal point of attention in future disputes concerning expropriation and the standards of treatment of foreign investors.

\section{H. THE PROTECTION OF COMPANIES AND SHAREHOLDERS}

In the Barcelona traction case the ICJ was not prepared to provide a legal remedy to the shareholders independently of the company. Barcelona Traction was a company established under Canadian law, doing business in Spain. The majority of shareholders were, however, Belgian nationals, on whose behalf Belgium brought legal action before the ICJ against Spain alleging that its activities had injured the company. Spain objected that since the alleged injury was to the company, not the shareholders, Belgium lacked the locus standi to bring the claim. In its judgement delivered in 1970, the ICJ upheld the Spanish objection:

'Notwithstanding the separate corporate personality, a wrong done to the company frequently causes prejudice to its shareholders. But the mere fact that damage is sustained by both company and shareholders does not imply that both are entitled to claim compensation ... whenever a shareholder's

416 Yustisia Vol. 7 Number 3 (Sept.-Dec. 2018) $\quad$ Fleshing Out The Provisions ... 
interests are harmed by an act done to the company, it is to the latter that he must look to institute appropriate action; for although two separate entities may have suffered from the same wrong, it is only one entity whose rights have been infringed.' (Barcelona traction, light and power co. case (Belgium v Spain), ICJ reports, 1970: 3)

However, in its judgement in the ELSI case delivered in 1989 the ICJ (Case concerning Elettronica Sicula S.p.A. (ELSI) (United States v Italy), ICJ reports, 1989: 15)) was sympathetic to the US argument that the injury suffered by the American shareholder, Raytheon, in ELSI, an Italian company, deserved compensation, although the Court was relying more heavily in this case on a provision contained within the FCN Treaty between Italy and the US.

\section{THE EXHAUSTION OF LOCAL REMEDIES}

In most of the cases considered by the international claims commissions and other international tribunals, whether ad hoc or permanent, including the Iran-US Claims Tribunal and the ICSID, the issue of the exhaustion of local remedies does not become a major issue. This is because these dispute settlement mechanisms would entertain cases by virtue either of a diplomatic agreement to refer the dispute to them or of:

a. bilateral agreement;

b. investment treaty; or

c. contract between the litigating parties providing for the settlement of disputes

by such bodies.

In the absence of such specific agreements or specific provisions in bilateral agreements, a litigating party is supposed to exhaust local remedies available in the state in question before taking the matter to international courts and tribunals.

The issue of exhaustion of local remedies rose before the ICJ in two cases: the Interhandel (Interhandel case (Switzerland v United states) (Preliminary objections), ICJ reports 1959: 26-30)) and ELSI (Case concerning Elettronica Sicula S.p.A. (ELSI) (United States v Italy), ICJ reports, 1989: 15) cases. While the rule on the exhaustion of local remedies was invoked successfully by the US in the former case, Italy was unsuccessful in its defence in the second case. In the ELSI case, the ICJ held that:

'It is never easy to decide, in a case where there has in effect been much resort to the municipal courts, whether local remedies have been truly "exhausted". But in this case Italy has not been able to satisfy the Chamber that there clearly remained some remedy, which Raytheon ... independently of ELSI, and of

ELSI's trustee in bankruptcy, ought to have pursued and exhausted.

Yustisia Vol. 7 Number 3 (Sept.-Dec. 2018) $\quad$ Fleshing Out The Provisions ... 
Accordingly, the Chamber will now proceed to consider the merits of the case.' (ICJ judgment : para.59 and 63)

In the Ambatielos case (23 ILR 306,1956 ) between Greece and the UK, the arbitration tribunal rejected the Greek claim against the UK made on behalf of $\mathrm{Mr}$ Ambatielos, a Greek national, on the ground of non-exhaustion of local remedies.

\section{J. TRIMs CASES}

Since the WTO Dispute Settlement Body (DSB) itself is a new one, there have been only a few cases that have dealt with foreign investment matters. Moreover, since the scope of the DSB is limited to interpreting the provisions of the TRIMS agreement, the WTO cases, unlike the ICSID cases, do not deal with traditional issues relating to foreign investment.

For instance, the case concerning certain measures affecting the automobile industry (WT/DS44/R, Panel report adopted by the DSB on 23 July 1998), referred to the DSB, conceived the compatibility of the Indonesian measures for local content requirements for the automobile industry with the TRIMS obligations of Indonesia. The TRIMS agreement is about freedom for foreign investors in a WTO member country. When the EC and the US challenged the Indonesian measures, the WTO Panel held that these measures were not consistent with Indonesia's obligations under the TRIMS agreement.

\section{K RECENT ATTEMPTS TO EXTEND THE FRONTIERS OF EXPROPRIATION}

Moving from the requirement under traditional international law to accord 'fair and equitable treatment' (Stephen Vasciannie, 1999: 99-164) to foreign investors, the FCN treaties concluded by the US with some developing states after the Second World War required 'full protection and security' to foreign investment mainly due to various waves of outright and creeping expropriations of the assets of Western companies in the developing world. The introduction of the concept of 'full protection and security' in certain FCN treaties became a norm in most BITs. The NAFTA and some BITs add the qualifying words 'as required by international law' after the words 'full protection and security'; some do not.

\section{FURTHER QUALIFICATIONS}

Where there is no reference to international law, the level of protection and security would be as that included in BITs or RTAs, which often provide a higher level of protection and security. Then, the notions of 'indirect' expropriation and

418 Yustisia Vol. 7 Number 3 (Sept.-Dec. 2018) $\quad$ Fleshing Out The Provisions ... 
'measures tantamount to expropriation' were introduced through the US Model BIT by the early 1980s and were later incorporated into the 1986 US-Canada Free Trade Agreement. They then found their way into the NAFTA.

Where the words 'full protection and security' and according 'fair and equitable treatment' are added they are meant to imply that foreign investors are entitled to greater protection. These are the phrases that the ICSID has employed rather generously in favour of foreign investors in many investment cases.

\section{A. Relevant case-law}

For instance, in the Metalclad Corporation v United Mexican states case, the ICSID held that the decision by a local government authority to withhold planning permission to construct a facility by Metalclad for the disposal of hazardous waste in accordance with the agreement between the company and the Mexican national government was regarded as a treatment that did not meet the standard of fair and just treatment under the NAFTA (ICSID Case No. ARB (AF)/97/1 of 30 August 2000; ICSID Review Foreign investment law journal, 2001: pp.165 ff). The award made by the ICSID tribunal adjudicating under the NAFTA showed how far the law of foreign investment relating to expropriation had moved in recent years from the narrow, traditional definition of the term based on the idea of 'taking foreign property' to a more or less an all-encompassing term:

'expropriation under NAFTA includes not only open, deliberate and acknowledged takings of property, such as outright seizure or formal or obligatory transfer of title in favour of the host state, but also covert or incidental interference with the use of property which has the effect of depriving the owner, in whole or in significant part, of the use or reasonably-to-be-expected economic benefit of property even if not necessarily to the obvious benefit of the host state.' (ICSID Case No. ARB (AF)/97/1 of 30 August 2000; ICSID Review Foreign investment law journal, 2001: pp.165 ff)

These types of awards (another being the award made in the Maffezini case (Emilio Augustin Maffezini v Kingdom of Spain (ICSID case): 124 ILR, 2003)) seek to push the frontiers of expropriation beyond not only the traditional definition of 'taking property', but also the so-called 'creeping expropriation' or 'constructive expropriation' or 'deprivation' advanced by the Iran-US Claims Tribunal.

These types of awards may give rise to challenges to any governmental regulatory measures, whether they are related to human rights or environmental protection, by foreign investors if such measures go against their interests. Similar trends seem to appear within the WTO's dispute settlement mechanism. After examining the

\begin{tabular}{ll|l}
\hline Yustisia Vol. 7 Number 3 (Sept.-Dec. 2018) & Fleshing Out The Provisions ... & 419
\end{tabular} 
consequences of the Metalclad case for host states, Lowe concludes that the award of the ICSID in this case could:

'encompass an enormous range of regulatory measures adopted by a state.

If such measures do indeed amount to expropriation, it follows as a necessary consequence that, unless the state fully and promptly compensates affected businesses, it has no right to take such measures. That is a very significant limitation upon the right of the state.'(Emilio Augustin Maffezini v Kingdom of Spain (ICSID case): 124 ILR , 2003).

By citing another award made by the ICSID not long before the Metalclad award (i.e. the award made in the Santa Elena case (Compania Del Desarrollo de Santa Elena S.A. v Republic of Costa Rica (2000), 39 ILM 1317, 2001:para.77) where the ICSID had taken a more traditional approach, Lowe goes on to state that '( $\mathrm{t}$ )he gap, and the consequent uncertainty concerning the extent of states' obligations towards investors, is a cause of real concern. Is there, one may ask, a clear and principled approach to the determination of the limits of a state's responsibilities?'(Lowe, note158, p.7)

\section{NAFTA and the ICSID}

In the Pope \& Talbot case (Pope and Talbot Inc. v Government of Canada: 122 ILR ,2002:293 ff.) the ICSID held that 'investors under NAFTA are entitled to the international law minimum, plus the fairness elements,' (Pope and Talbot Inc. v Government of Canada: 122 ILR, 2002 :para.77) implying that the NAFTA provided greater protection than that provided under international law. However, this interpretation was criticised by a Canadian Court for being a wrong interpretation of Article 1105 of the NAFTA which requires 'treatment in accordance with international law, including fair and equitable treatment and protection and security', implying that the 'fairness elements' were part and parcel of international law (United Mexican states v Metalclad Corporation, Judicial review, Supreme Court of British Columbia, (Tysoe J.),ICSID Reports, 2002)

Perhaps realising that the ICSID tribunals were taking things too far, a declaration issued by the three states party to the NAFTA, viz., Canada, Mexico and the United States, endorsed the position taken by the Canadian Court in the following terms: "The concepts of "fair and equitable treatment" and "full protection and security" do not require treatment in addition to or beyond that which is required by customary international law minimum standard of treatment of aliens.' (St Paul, Minn, 2002: 1166)

Even then it is doubtful whether the leaders of these three countries were correct in their interpretation of customary international law minimum standards. What should be noted here is that the NAFTA provision itself goes slightly beyond what

420 Yustisia Vol. 7 Number 3 (Sept.-Dec. 2018) $\quad$ Fleshing Out The Provisions ... 
is covered by the 'international minimum standard' prescribed by classical rules of customary international law.

The NAFTA is not necessarily a good example of lex generalis on the standards of treatment of foreign investment, but an example of, like other BITs, lex specialis agreed among the contracting parties. Although Appleton has asserted on the basis of the pronouncements made in cases such as Metalclad and Pope \& Talbot that 'a substantial part of the controversy' over the meaning of expropriation in international law 'has been settled',(Barry Appleton, 2001: 198) it is difficult to agree with such an assertion. The awards made by the ICSID tribunals either under the BITs or the NAFTA should be treated with some caution as far as their implications for international law of investment are concerned. The message running through the awards made by the ICSID tribunals is the curtailment of the regulatory rights of sovereign states in favour of foreign investors. Lowe has summed up the situation:

'The tenor of the cases [i.e., the ICSID cases] suggests that it is now regarded as "unfair" or "inequitable" for a state to make material changes in the business environment that prevailed when the investor committed itself to its investment. The impact of the "fair and equitable treatment" obligation on the freedom of a government to regulate its economy is potentially very considerable indeed.

These, and other, applications of the fair and equitable standard, point towards an exceptionally wide interpretation of that standard, greatly favouring investors. The same trend is evident in respect of the obligation to accord full protection and security to investments. That phrase, common in British and American BITS, but not generally found in French, German, Italian or Swiss BITS, plainly requires states to protect investments against physical destruction. It plainly requires states to maintain a legal system in which investors can obtain remedies against breaches of contract and unfair commercial practices visited upon them by third parties. All of that is implicit in the minimum international standard. It seems, however, to be coming to be applied so as to require states to intervene, and to act positively to protect investors against such practices and transactions.' (Lowe, note 158, p.21)

\section{A. Relevant case-law}

Indeed, the trend seen in cases like Metalclad and Maffezini (Emilio Augustin Maffezini v Kingdom of Spain (ICSID case): 124 ILR ,2003) go somewhat beyond the level of protection accorded to foreign investors under customary international law. Accordingly, it becomes necessary to return to the provisions of international instruments and the pronouncements of international courts and tribunals that apply

\begin{tabular}{ll|l}
\hline Yustisia Vol. 7 Number 3 (Sept.-Dec. 2018) & Fleshing Out The Provisions ... & 421
\end{tabular} 
lex generalis rather than lex specialis in deciding cases submitted to them, in order to establish the status of the rules of foreign investment.

Although the views taken by other NAFTA panels in other cases before Metalclad (Pope \& Talbot) and after Metalclad (S.D. Myers, Inc.v Canada) were slightly different and much narrower in interpreting the terms 'expropriation' or 'measures tantamount to expropriation' and the panel in Metalclad itself was measured in its interpretation of the impact of non-discriminatory regulation on foreign investors, there is a great deal of inconsistency in the jurisprudence of the BIT or NAFTA tribunals. Referring to the regulatory measures of the Canadian government and interpreting the provisions of Article 1110 of the NAFTA Treaty the panel in the Pope

$\&$ Talbot case held that it did 'not believe that those regulatory measures constitute an interference with the Investment's business activities substantial enough to be characterised as expropriation under international law.'(Lowenfeld, A, 2003: 477-478)

The panel held that it did not regard that the phrase 'measure tantamount to nationalisation or expropriation' in Article 1110 broadened the ordinary concept of expropriation under international law so as to require compensation.

Unlike the generous views taken in the Metalclad case, the panel held in this case that the export control regime of Canada did not cause an expropriation of the investor's investment, creeping or otherwise. The panel went on to state that:

'[w]hile it may sometimes be uncertain whether a particular interference with business activities amounts to an expropriation, the test is whether that interference is sufficiently restrictive to support a conclusion that the property has been 'taken' from the owner.'

Thus, the panel in this case was not willing to accord to the NAFTA provision a wider meaning than that provided for in customary international law. A similar view was taken in S.D. Myers $v$ Canada (Lowenfeld, A, 2003: 479).

The panel in this case took a clear position on the distinction between expropriation and regulatory measures:

'Expropriations tend to involve the deprivation of ownership rights; regulations a lesser interference. The distinction between expropriation and regulation screens out most potential cases of complaints concerning economic intervention by a state and reduces the risk that governments will be subject to claims as they go about their business of managing public affairs.'

In Feldman $v$ Mexico (42 ILM, $2003: 625$ ) an ICSID panel did not find that the application of certain tax laws by Mexico against the claimant were tantamount to expropriation. It did, nevertheless, find that Mexico had acted inconsistently with its

422 Yustisia Vol. 7 Number 3 (Sept.-Dec. 2018) $\quad$ Fleshing Out The Provisions ... 
other obligations under NAFTA. Indeed, due to the excesses of protection provided to foreign investors in awards such as those in the Metalclad case, the NAFTA Free Trade Commission issued some 'clarifications' relating to certain provisions of NAFTA and mainly the nature and scope of Article 1105. The Commission defined the minimum standard of treatment in accordance with international law available to foreign investors under the NAFTA provisions in the following words:

'Minimum Standard of Treatment in Accordance with International Law Article 1105 (1) prescribes the customary international law minimum standard of treatment of aliens as the minimum standard of treatment to be afforded to investments of investors of another Party.

The concepts of 'fair and equitable treatment' and 'full protection and security' do not require treatment in addition to or beyond that which is required by the customary international law minimum standard of treatment of aliens.

A determination that there has been a breach of another provision of NAFTA, or of a separate international agreement, does not establish that there has been a breach of Article 1105 (1).' (St.Paul, Minn, 2002: 1166).

Similarly, in Occidental exploration and production company $v$ The Republic of Ecuador, Occidental, an American company, invoked the BIT between Ecuador and the US in a matter involving non- reimbursement of VAT to the company by the Government of Ecuador in a case decided by the London Court of Arbitration under an UNCITRAL arbitration (London Court of Arbitration, Final award in the matter of an UNCITRAL arbitration: Occidental Exploration and Production Company v The Republic of Ecuador (Case No. UN 3467) (July 1, 2004)).

The company alleged that by not reimbursing VAT to them Ecuador failed, inter alia, to accord its investment fair and equitable treatment and treatment no less favourable than that required by international law and expropriated, directly or indirectly all or part of its investment in violation of the internationallyaccepted norms of the treatment of foreign investment. Using the narrower criterion of 'substantial deprivation' under international law identified in Pope \& Talbot, the tribunal dismissed Occidental's claim of expropriation.

Nevertheless, some other ICSID cases dealing with the issue of 'full protection and security' provided to foreign investors under BITs from the host state have raised controversy as to the meaning and scope of this phrase. In some cases the ICSID panels have gone on to interpret this phrase rather generously. Under it governments would in effect be expected to deploy the police and the army for the protection of foreign investors free of charge in the event of civil strife and armed insurgence within the country.

\begin{tabular}{ll|l}
\hline Yustisia Vol. 7 Number 3 (Sept.-Dec. 2018) & Fleshing Out The Provisions ... & 423
\end{tabular} 
As stated by Lowenfeld, 'BITs seem to require the government of the host state not only not to attack the facilities or personnel of the investor, but to defend the investor or investment against others, including, for instance, rebel forces.'

Indeed, in the Asian Agricultural Products Ltd. v Republic of Sri Lanka case an ICSID tribunal established Sri Lanka's state responsibility for failing to take the appropriate precautionary measures to protect the interests of Asian Agricultural Products, a British company having its business in an area where fighting was taking place between the government and rebel forces (Asian Agricultural Products Ltd. v Republic of Sri Lanka, 30 ILM, 1991: 577, para.85-86).

A variety of state activities have been declared by various international courts and tribunals to be measures tantamount to expropriation or creeping or indirect forms of expropriations. Sampliner produces the following list of such activities based on the decisions of various courts and tribunals:

i. Prohibition of sale or disposition of property, through measures that were reasonably believed to be permanent or of indefinite duration;

ii. Forced sale of property to others at grossly substandard prices, following physical harassment or threats to employees or management, government-organised boycotts, or arbitrary refusals to permit investors to operate;

iii. Imposition of taxation that is consfiscatory in magnitude;

iv. Creeping expropriations (relatively minor individual actions, possibly legitimate when considered individually, that cumulatively result in a taking), e.g.:

(a) harassing employees, blocking their access to a plant, taking over a key supplier and then refusing to supply the company;

(b) government announcement of its ultimate intent to nationalize the bauxite industry, followed by a new severe bauxite tax, revision of a Mining Act to require minimum production quotas and higher royalties, and repudiation of other contract provisions (where the contract included a stabilisation clause);

(c ) imposing a 45-50\% tax on rental income from property, followed by a requirement of $30 \%$ withholding for a building repair account, and controls on identity of tenants.

i. Forced appointment of a Manager, Supervisor or Receiver who deprives a company of various fundamental rights or benefits of ownership, such as collecting and remitting the proceeds of sales;

ii. Deprivation of contractual rights to produce future goods and/or services;

iii. Government creation of a monopoly for itself or another preferred supplier, thereby putting an established company out of business;

424 Yustisia Vol. 7 Number 3 (Sept.-Dec. 2018) $\quad$ Fleshing Out The Provisions ... 
iv. The granting of 'cultivation licenses' to Panamanian peasants for portions of a claimant's land.' (Sampliner, G.H. 'Arbitration of expropriation cases under US investment treaties - a threat to democracy or the dog that didn't bark?', 18 (1) ICSID Review: Foreign investment law journal, 2003 : pp.1-43 at 8-9)

Given the recent trends it is conceivable that in due course foreign investors would demand full protection against terrorist activities at the expense of the host state and in the event of terrorist attacks claim compensation against the host states for failing to prevent such attacks. It is possible that the doctrine of state responsibility would be stretched to the limit to argue that the host state concerned failed in its obligation to provide 'full protection and security' to the foreign investor. Although there have been quite a few expropriation cases in which regulatory measures of states have not been regarded as measures constituting expropriation, the tendency in some of the cases examined earlier has been to regard many regulatory measures as constituting 'creeping' expropriation.

The three-part test prescribed by the US Supreme Court in a landmark case of Penn Central Transportation Co. v New York City (438 US 104, 124 (1978), Sampliner,) is illustrative. In order to establish whether a regulatory measure was tantamount to expropriation that measure had to be examined against the following three tests:

1. the economic impact of the regulation on the claimant;

2. the extent of interference with the property owner's reasonable investmentbacked expectations;

3. the character of the government action.( 438 US 104, 124 (1978), Sampliner,)

Although this municipal law case has not been cited openly as a source of authority by international courts and tribunals, this three- part test seems in the legal literature to have had a measure of influence. Article 114(2) of NAFTA preserves the 'police powers' of states in the following words:

'Nothing in this chapter shall be construed to prevent a Party from adopting, maintaining or enforcing any measure otherwise consistent with this chapter that it considers appropriate to ensure that investment activity in its territory in undertaken in a manner sensitive to environmental concerns.'

\section{N. CLOSING CONSISTING OF CONCLUSION AND SUGGESTION}

It seems to be agreed that only if a regulatory measure in question interferes with the investor's legitimate and reasonable expectations in making the investment does it constitute expropriation. Regulations that impose general limitations on the

\begin{tabular}{ll|l}
\hline Yustisia Vol. 7 Number 3 (Sept.-Dec. 2018) & Fleshing Out The Provisions ... & 425
\end{tabular} 
activities of the investors to protect the general interest of the public would not be regarded as expropriation. In addition, the regulatory measures in question have to be subjected to other tests, including proportionality.

\section{BIBLIOGRAPHY}

\section{Books:}

Amerasinghe, C.F, 1994, 'Assessment of compensation for expropriated foreign property: three critical problems' in Ronald St John Macdonald (ed.), Essays in honour of Wang Tieya, Martinus Nijhoff: London.

Bowett, D.W, 1988, 'State contracts with aliens: contemporary developments on compensation for termination or breach', BYIL.

Brownlie, I, 1977, 'Treatment of aliens: assumptions of risk and international law', in Flume, W. et al. (eds), international law and economic order: essays in honour of F.A. Mann.

Chowdhury, S.R. et al. (eds), 1992, The right to development in international law, Martinus Nijhoff: Dordrecht

Fischer Williams, J, 1928, 'International Law and the Property of Aliens', BYIL.

Francioni, F, 1975, 'Compensation for nationalisation of foreign property: the borderland between law and equity',CLQ

Higgins, R, 1982, 'The taking of property by the state: recent developments in international law', Recueil des cours

Hossain, K. (ed), 1980, Legal aspects of a new international economic order, Frances Pinter: London

Jimenez de Arechaga, E, 1978, 'State responsibility for the nationalisation of foreign-owned property', 11 NYUJIL \& Pol.

Schrijver, N, 1997, Sovereignty over natural resources; balancing rights and duties, Cambridge University Press: Cambridge.

Schwarzenberger, G, 1972, International law and foreign investment. Seidl-

Hohenveldern, I, 1980, 'International economic soft law', Hague Recueil

Shihata, I.F.I, 1991, The World Bank in a changing world: selected essays, Dordrecht: Martinus Nijhoff.

United Nations Conference on Trade and Development, World Investment Report 2003, fdi policies for development: national and international perspectives, New York and Geneva: United Nations (UN Sales No. E.03.II.D.8).

\begin{tabular}{l|ll}
426 & Yustisia Vol. 7 Number 3 (Sept.-Dec. 2018) & Fleshing Out The Provisions ...
\end{tabular} 
UNCTAD, 2003, World investment report 2003: FDI policies for development: national and international perspectives, New York/Geneva: United Nations.

Vasciannie, S, 1999, 'the fair and equitable treatment standard in international investment law and practice', 70 BYIL.

Verwey, W.D. and N.J. Schrijver, 1984, 'The taking of foreign property under international law: a new legal perspective?' XV Netherlands yearbook of international law.

\section{Journals and Proceeding:}

Appleton, B, 2001, 'Investment disputes and NAFTA chapter 11', ASIL proceedings of the 95th Annual Meeting

Bean, V. and Beauvais, J.C. 'The global fifth amendment? NAFTA's investment protections and the misguided quest for an international 'regulatory takings' doctrine' 78 New York University Law Review (April 2003).

Sampliner, G.H. 'Arbitration of expropriation cases under US investment treaties - a threat to democracy or the dog that didn't bark?', 18 (1) ICSID review: foreign investment law journal (Spring 2003),

Vandevelde, K.J, 1992, 'The BIT program: a fifteen-year appraisal', Proceeding of the ASIL 86th Annual Meeting, 